\title{
Integritas kepuasan hidup korban KDRT
}

\author{
Arnaldy Arnaldy ${ }^{1}$, Herman Nirwana $^{2}$, Afdal Afdal ${ }^{3 *}$ \\ ${ }^{123}$ Universitas Negeri Padang
}

\begin{tabular}{l}
\hline Article Info \\
\hline Article history: \\
Received Jun $6^{\text {th }}, 2020$ \\
Revised Jul $10^{\text {th }}, 2020$ \\
Accepted Aug $7^{\text {th }}, 2020$
\end{tabular}

\section{Keyword:}

Life satisfaction

KDRT

\begin{abstract}
Life satisfaction (kepuasan hidup) adalah penilaian individu secara reflektif tentang seberapa baik terpenuhi dalam kehidupannya dalam aspek psikologis. Penelitian ini dilakukan terhadap dua orang istri korban KDRT sebagai subjek penelitian, dengan usia pernikahan 4 tahun dan 16 tahun. Teknik pengambilan data melalui wawancara dan observasi dengan analisis reduction data, data display and conclusion drawing and verification. Teknik menjamin keabsahan data dengan cara triangulasi. Hasil penelitian menunjukkan, life satisfaction korban KDRT sama-sama kurang baik. Namun ada perbedaan dalam hal aspek integritas. Subjek penelitian pertama lebih baik dalam aspek integritas keluarga. Sedangkan YI jauh lebih baik dalam hal integritas pribadi. Jadi, life satisfaction dalam hasil penelitian secara menyeluruh terungkap YI lebih baik daripada EF karena penderitaan KDRT yang dialaminya tidak mengganggu komitmen pernikahannya. Implikasi dalam Bimbingan dan Konseling, diarahkan pada kajian kompetensi konselor dalam melakukan intervensi psikologis untuk mengembangkan life satisfaction korban KDRT dalam layanan BK.
\end{abstract}

(C) 2020 The Authors. Published by IICET.

This is an open access article under the CC BY-NC-SA license (https://creativecommons.org/licenses/by-nc-sa/4.0

\section{Corresponding Author:}

Afdal,

Universitas Negeri Padang

Email: afdal@konselor.org

\section{Pendahuluan}

Life satisfaction (Kepuasan hidup) dalam pernikahan ditinjau dari penilaian positif atau negatif dalam kualitas hubungan dengan pasangan ( Afdal, A., Arnaldy, A., Nirwana, H., Alizamar, A., Zikra, Z., Ilyas, A., \& Fikri, M., 2019). Pernikahan secara psikologis membentuk keluarga yang bertujuan mewujudkan kesejahteraan dan kepuasan hidup (Muhid, Nurmamita, \& Hanim, 2019). Keluarga merupakan tempat pertama memperoleh pendidikan berupa bimbingan dan kasih sayang yang layak (Aressa, Nirwana, \& Bentri, 2016). Idealnya, tujuan pembentukan keluarga agar setiap anggota keluarga saling merasakan ketentraman, kasih sayang dan rasa cinta (Ainiyah \& Mufarida, 2019). Hasil penelitian menunjukkan bahwa secara psikologis, semakin baik penyesuain diri, maka semakin baik kesejahteraan psikologis (Wulandari, 2016). Semakin baik kesejahteraan psiologisnya, maka kepuasan hidup akan tercapai. Oleh karena itu diharapkan pernikahan dapat memenuhi life satisfaction setiap pasangan dan anggota keluarga.

Secara umum, Life satisfaction (kepuasan hidup) adalah penilaian kognitif individu dengan menganggap hidupnya sebagai keseluruhan atau dalam bidang kehidupan tertentu, seperti hubungan sosial, lingkungan kerja, keluarga ataupun dirinya sendiri (State \& Kern, 2017). Life satisfaction merupakan evaluasi kognitif dari keseluruhan perasaan dan sikap tentang kehidupan individu secara reflektif (Vassar, 2012). Life satisfaction adalah sebuah kebutuhan atau ekspektasi yang bersifat subjektif pada masing-masing individu yang berhubungan dengan kemauan untuk merubah diri, penghayatan suatu situasi kondisi, menikmati hidup dan persaan gembira (Hurlock, 2004). Life satisfaction seseorang berupa penilaian secara kognitif seberapa besar memuaskannya pengalamn-pengalaman pada seluruh area hidup yang menjadi penting dari individu itu 
sendiri (Asih, Yuliadi, \& Karyanta, 2010). Jadi, life satisfaction adalah penilaian individu secara kognitif dan reflektif tentang seberapa baik terpenuhinya di dalam kehidupan. Life satisfaction dapat diukur dari aspek masa lalu, masa sekarang dan masa yang diharapkan. Hal ini sama dengan mengukur suject well being (Maddux, 2018). Kepuasan hidup individu berupa penilaian reflektif dalam kehidupannya (Asih et al., 2010). Jadi, life satisfaction adalah penilaian atau evaluasi individu secara kognitif dan reflektif tentang seberapa baik dan terpenuhinya dalam kehidupan.

Pernikahan seyogyanya dapat saling meningkatkan kepuasan hidup yang terlihat dalam bentuk kerja sama, saling berkasih sayang, komitmen dan komunikasi positif. Kenyataan yang terjadi di lapangan masih ditemukan terjadinya kasus kekerasan dalam rumah tangga (KDRT). Masalah KDRT akhir-akhr ini semakin banyak dan mengkhawatirkan. KDRT umumnya dialami perempuan baik secara fisik maupun psikologis (Ramadani \& Yuliani, 2017). Oleh karena itu secara yuridis, korban KDRT memerlukan perlindungan hukum yang adil (Abdurrachman, 2016).

KDRT dikenal dengan domestic violence diartikan sebagai kekerasan fisik, kekerasan seksual, kekerasan psikologis dan kekerasan ekonomi yang terjadi dalam hubungan rumah tangga (Field, Onah, Heyningen, \& Honikman, 2018). Tindakan KDRT juga terjadi dalam bentuk penelantaran dan perampasan yang dilakukan pelaku terhadap korban (Kesowo, 2004). Hasil penelitian yang dilakukan (Field et al., 2018) memperlihatkan bahwa KDRT banyak terjadi di daerah perkotaan yang sebagian kasusnya tidak dilaporkan kepada polisi maupun ke pusat layanan kesehatan dan cenderung kasus tersebut bersifat privasi. KDRT yang terjadi di lingkungan perkotaan disebabkan oleh beberapa faktor seperti faktor ekonomi, faktor status pernikahan, dan faktor kurangnya pengamalan agama (Kantor Urusan Agama Kecamatan Padang Barat, 2019). Korban KDRT umumnya terjadi pada perempuan karena keterbatasan secara kekuatan fisik dan mental sebagai istri (Ramadani \& Yuliani, 2017).

Korban KDRT selaku individu yang mengalami penderitaan, kerugian fisik dan mental, ekonomi dan sosial atau hak-hak dasar yang disebabkan oleh pelanggaran hukum pidana penyalahgunaan kekerasan oleh pelaku (Soeroso, 2012). Beberapa dampak KDRT terhadap korban secara fisik berupa kerusakan bagian anggota tubuh, memar, bentuk luka tertentu (Ramadani \& Yuliani, 2017). Secrara fisik, korban dapat mengalami rasa nyeri, dehidrasi, kesulitan tidur, disfungsi seksual dan gangguan fisik lainnya (Rahardjo, 2007) Selain itu secara fisik dapat mengarah kepada ancaman pembunuhan (Soeroso, 2012). Secara psikologis terhadap korban KDRT menimbulkan terganggunya pemaknaan individu, kesejahteraan dan otonomi diri (Yeni \& Lianawati, 2009). Secara psikologis dampak terhadap korban, yaitu reaksi emosional yang berlebihan, depresi, ketidakmampuan dalam mengasuh serta memenuhi kebutuhan anak-anak dan mengakibatkan kematian (Rahardjo, 2007).

Beberapa dampak psiklogis dialami korban KDRT, salah satunya kepuasan hidup (life satisfaction. Pernikahan yang berlangsung terbukti mengalami kepuasan hidup yang rendah terhadap korban KDRT (Nockita, 2016). Sementara itu, kepuasan hidup dalam pernikahan mengacu pada penilaian pasangan terhadap hubungan pernikahan apakah sudah baik atau buruk. Sebaliknya dalam berbagai penelitian terungkap bahwa kepuasan hidup dalam pernikahan pada korban kdrt cenderung menurun disebabkan terjadinya agresi kekerasan fisik terhadap korban (Stith, Green, Smith, \& Ward, 2008). Kepuasan hidup korban KDRT berdampak signifikan terhadap kesehatan mentalnya yang mana ditandai dengan munculnya kecemasan, deperesi, ketakutan dan keputusasaan dalam menjalani hubungan pernikahan (Fergusson et al., 2015). Jadi, dapat disimpulkan bahwa KDRT dapat berdampak secara fisik dan psikologis terhadap korban. selain itu, berdampak pada perlakuan korban terhadap anak-anak dalam mendidik menjadi ikut kasar karena mengalami emosi yang tidak stabil.

World Health Organization), 1 dari 3 orang perempuan di dunia mengalami kekerasan secara fisik dan kekerasan seksual oleh pasangannya (WHO, 2017). Kekerasan terhadap istri berada pada urutan tertinggi, diikuti oleh kekerasan terhadap anak serta perempuan (Komnas Perempuan, 2019). Sumatera Barat tergolong tinggi dalam kasus KDRT dari tahun 2014 hingga tahun 2017. Tahun 2014 berjumlah 81 kasus kekerasan terhadap perempuan yang terdiri dari 38 kasus kekerasan seksual, 40 kasus KDRT dan 9 kasus lainnya. Tahun 2015 mengalami peningkatan sebanyak 85 kasus, 45 kasus kekerasan seksual, 35 kasus KDRT, 4 kasus perdagangan manusia, 1 kasus kekerasan pacaran, dan 1 non kasus kekerasan berbasis gender. Selanjutnya, tahun 2016 meningkat menjadi 109 kasus, 54 kasus kekerasan seksual, 43 kasus KDRT, 6 kasus perdagangan manusia, 2 kasus kekerasan dalam pacaran, dan 4 kasus non kekerasan berbasis gender. Tahun 2017 tercatat 90 kasus kekerasan berbasis gender yang 46 kasus merupakan kekerasan seksual, sebagaimana yang disampaikan oleh Direktur Womens's Crisis Center Nurani Perempuan Yafri Afriani (Arya, 2017) . Sementara itu, Kota Padang tercatat sebagai kota dengan kasus perempuan korban KDRT tertinggi di Sumatera Barat. Terdapat 151 kasus yang terdiri dari 135 kasus kekersan fisik, 2 kasus kekersan psikis, 3 
kekerasan seksual dan 11 kasus penelantaran atau pengabaian (Dinas Pemberdayaan Perempuan, 2017). Hasil penelitian memperlihatkan terdapat perbedaan signifikan kekerasan yang dialami korban perempuan dari segi usia pernikahan, ternyata wanita yang usia pernikahan lebih rendah cenderung mengalami kekerasan yang lebih tinggi dibandingkan wanita korban KDRT yang berada di usia pernikahan yang lebih tinggi (Afdal Afdal, Alizamar, Ifdil, Erlamsyah, \& Taufik, 2017). Artinya, semakin tinggi usia pernikahan seharusnya semakin kurang terjadinya KDRT.

Beberapa aspek dalam life satisfaction, yaitu : (1) penerimaan; mengacu pada penyesuaian diri dan sosial yang baik, (2) kasih sayang; mengarah kepada hasil dari normal sikap diterima orang lain berupa kasih sayang, (3) prestasi; berupa tercapainya tujuan idividu dalam bentuk segenap potensi, kerja keras dan pengorbanan diri, seperti dapat memperoleh uang dan kekuasaan (Hurlock, 2004). Beberapa faktor yang menetukan kepuasan hidup individu (Linsiya, 2015) , seperti (1) faktor umur, (2) status ekonomi dan pendapatan, (3) pekerjaan, (4) status perkawinan dan dukungan sosial dari keluarga, (5) kepribadian individu yang tergolong dalam kompetensi, (6) riwayat pengalaman penting, (7) konsep diri yang mengarah pada pandangan diri baik kelebihan atau kekurangan diri (Chang, McBride-Chang, Stewart, \& Au, 2003) dan (8) religuisitas yang berperan terhadap kepuasan hidup (Lim \& Putnam, 2010). Selain itu, kepuasan hidup juga dipengaruhi oleh faktor kualitas komunikasi, kesamaan visi mendidik anak, keuangan dan riwayat-riwayat masalah yang dialami setiap pasangan (Najarpourian et al., 2012).

Life satisfaction yang dibahas dan dideskripsikan dalam penelitian ini mengacu pada beberapa aspek integritas korban KDRT, yaitu sense of personality integrity (rasa integritas pribadi) dan sense of family integrity atau integritas keluarga (Kabasakal, 2015). Sense of personality integrity (integritas pribadi) berkaitan dengan etika dan nilai moral individu yang berlaku secara normatif di lingkungan masyarakat. Integritas pribadi tergambar dalam sikap kesatuan antara perbuatan dan perkataan. Beberapa ciri-ciri integritas pribadi, yaitu bertanggung jawab, komitmen terhadap tugas atau janji, senantiasa konsisten dan bersikap jujur. Integritas pribadi berperan penting terhadap kesuksesan dalam berumah tangga. Kepuasan hidup yang berkembang dengan ditunjukkan pada integritas pribadi yang positif. Namun, kekerasan yang terjadi dapat mempengaruhi integritas pribadi korban, seperti persaan sadar bertanggung jawab dan kesetiaan dapat terganggu (Tamelab, 2020).

Sense of family integrity (integritas keluarga) ditampilkan dalam bentuk keteladanan terutama sebagai orangtua yang menyangkut sikap, perkataan, perbuatan, pengamalan agama, kesabaran dan sikap memaafkan. Keteladanan dalam pengamalan nilai-nilai agama dalam keluarga menjadi dasar perilaku yang diperlukan dalam kehidupan secara menyeluruh (Fautanu, 2011). Jadi, kepuasan hidup korban KDRT dapat dilihat dari seberapa baik aspek integritas keluarga. Korban KDRT yang cukup baik dalam integritas pribadinya, maka dapat terlihat dari sikap keteladanan dalam pengamalan nilai agama, kesabaran dan memaaffkan terhadap pelaku.

\section{Metode}

Jenis penelitian yang digunakan adalah penelitian kualitatif jenis studi kasus. Subjek penelitian atau responden yang diambil dalam penelitian ini berjumlah dua orang istri korban KDRT yang diambil secara accidental sampling. Berikut data masing-masing subjek penelitian pada tabel 1.

Teknik dan alat pengumpulan data dengan wawancara dan observasi. Teknik pemeriksaan keabsahan data dilakukan dengan mengulangi pengamatan di lapangan, wawancara mendalam dan trangulasi (Creswell, 2007). Teknik analisis data yang dilakukan dengan model interaktif melalui tahapan pengumpulan data, reduksi data, diplay data dan penarikan kesimpulan (Miles \& Huberman, 1992). Diplay data dilakukan dengan pengumpulan data masing-masing subjek dan beberapa informan terkait, membuat kategori tema dan proses pengkodean sesuai dengan aspek life satisfaction korban KDRT. Kemudian, dapat ditarik kesimpilan berupa gambaran life satisfaction korban KDRT.

Tabel 1. Data Subjek Penelitian 


\begin{tabular}{|c|c|c|}
\hline DATA & SUBJEK 1 & SUBJEK 2 \\
\hline Inisial & $\mathrm{EF}$ & YI \\
\hline Usia & 45 tahun & 37 tahun \\
\hline Pendidikan & Tamat SMA & Tamat SMP \\
\hline Pekerjaan & Berjualan rokok & Berjualan kelapa muda \\
\hline Status Pernikahan & Pernikahan kedua secara siri & Pernikahan kedua secara siri \\
\hline Lama Pernikahan & 4 tahun & 16 tahun \\
\hline Anak & 2 orang dari pernikahan pertama & $\begin{array}{l}3 \text { orang ( } 1 \text { dari pernikahan } \\
\text { pertama \& } 2 \text { dari pernikahan } \\
\text { kedua }\end{array}$ \\
\hline Jenis kekerasan & Fisik dan Verbal & Fisik dan Verbal \\
\hline \multirow{5}{*}{ Tanggal wawancara } & 1. 2 Desember 2020 & 1. 1 April 2020 \\
\hline & 2. 9 Maret 2020 & 2. 9 April 2020 \\
\hline & 3. 10 April 2020 & 3. 14 April 2020 \\
\hline & 4. 20 Mei 2020 & 4. 20 Mei 2020 \\
\hline & 5. 22 Mei 2020 & 5. 22 Mei 2020 \\
\hline \multirow[t]{6}{*}{ Tanggal observasi } & 1. 28 Februari 2020 & 1. 1 April 2020 \\
\hline & 2. 9 Maret 2020 & 2. 6 April 2020 \\
\hline & 3. 25 April 2020 & 3. 18 April 2020 \\
\hline & 4. 18 Mei 2020 & 4. 16 Mei 2020 \\
\hline & 5. 20 Mei 2020 & 5. 22 Mei 2020 \\
\hline & 6. 22 Mei 2020 & 6. 30 Mei 2020 \\
\hline \multirow[t]{4}{*}{ Triangulasi dengan informan } & 1. Wawancara dengan Anak EF & $\begin{array}{l}\text { 1. Wawancara dengan teman } \\
\text { dekat YI }\end{array}$ \\
\hline & 3. Wawancara dengan teman dekat & 2. Wawancara dengan suami YI \\
\hline & EF & 3. Wawancara dengan mama YI \\
\hline & & 4. Wawancara dengan adik YI \\
\hline
\end{tabular}

\section{Hasil dan Pembahasan}

Hasil temuan dalam penelitian ini menjelaskan tentang aspek kondisi life satisfaction (kepuasan hidup) korban KDRT dalam hal integritas.

\section{Sense of personality inttegrity}

Kepuasan hidup yang berkembang dengan baik ditunjukkan pada integritas pribadi yang positif. Namun, adanya KDRT yang dialami responden penelitian berdampak pada integritas pribadi. Dampak terhadap integritas pribadi yang dialami responden pertama (EF) yaitu, adanya sikap kurang komitmen serta inkonsistensi terhadap pernikahan. Hal ini sejalan dengan penelitian yang dilakukan oleh (Tamelab, 2020) memperlihatkan bahwa KDRT yang dialami korban dapat berdampak pada komitmen dan konsistensinya.

Subjek pertama selama ini mengakui sering tidak jujur terhadap suami dalam urusan keluar rumah dan dalam hubungan khusus dengan pria lain. Terungkap dalam wawancara dengan pernyaatannya sebagi berikut:

Saya kalau pergi keluar rumah sering tidak memberi tahu dan suka berbohong kepada suami". "Penyadaran dari kondisi KDRT yang saya alami memang karena selama ini saya kurang jujur, misalnya berjalan dengan teman tapi tidak meminta izin" (wawancara, 10 April 2020) . "EF mengakui memiliki hubungan khusus dengan mantan pacarnya dengan menghubungi lewat handphone lain yang EF miliki tanpa sepengetahuan suami" kata teman dekat EF. Pengakuan EF masih berkomunikasi dan bertemu langsung dengan laki-laki lain disebabkan EF sangat terdesak secara keuangan sehingga EF sering diberi uang dan bahan kebutuhan pokok untuk kelangsungan hidup anak-anaknya (WW, 22 Mei 2020).

Selain itu, subjek pertama masih kurang konsisten dalam bersikap setelah terjadi KDRT. Hal ini disebabkan karena EF masih mencintai suaminya dan terkadang berniat ingin meminta cerai kepada suaminya. Terbukti saat bertengkar EF menyatakan bahwa:

"tolong tinggalkan saja kami bertiga kalau abang masih tidak senang". Sebaliknya, saya berusaha kembali menjemput suami dari rumah orangtuanya setelah bertengkar dan berkata kasar pada saya. Mertua saya berkata, "kemarin kamu usir dia, sekarang kamu jemput lagi" (WW, 19 Maret 2020). 
Secara integritas pribadi responden pertama (EF) kurang baik karena tidak jujur kepada suami. Selain itu, inkonsistensi dan komitmen pernikahan terganggu oleh faktor kekerasan yang dialaminya. Hasil penelitian memperlihatkan terdapat hubungan yang positif antara secure dengan komitmen dalam pernikahan (Khumairoh \& Undarwati, 2015). Secure di sini dapat berupa keamanan dan perlindungan dalam hubungan pernikahan. Artinya, ketika secured korban KDRT yang bermasalah, maka berpengaruh terhadap komitmen pernikahan korban yang terkhusus dialami oleh responden pertama.

Adapun relevansi integritas pribadi dalam kaidah agama, memperlihatkan bahwa EF mencari kepuasan hidup hanya terfokus pada faktor luar. EF merasa begitu pentingnya perlakuan suami kepadanya dengan baik, kecukupan nafkah dan kebutuhan pokok. Menurut pemikiran tasawuf Hamka dikatakan bahwa kebahagiaan dan kepuasan hidup intinya bersal dari dalam diri, berupa rasa syukur, ikhlas dan puas dengan apa yang ada saat ini dengan mengharapkan keredhoan Allah (Arrasyid, 2019). Hal ini memngakibatkan EF mencari jalan negatif dengan tidak jujur dan kurang komitmen. Selain itu, dalam bahasan spiritual, perilaku muraqobah (merasa diawasi oleh Allah SWT) terhadap dosa (Syatibi, 2013). Sikap muraqabah belum terinternalisasi dalam keyakinan EF sehingga mengambil jalan pintas negatif untuk memenuhi kebutuhan hidup dan membayar hutang. Jadi, dapat disimpulkan EF memiliki life satisfaction yang rendah dalam aspek integritas pribadi berupa kejujuran dan komitemen yang tidak bagus.

Subjek kedua (YI) memiliki komitmen dan konsistensi yang cukup baik untuk mempertahankan keluarga. Hal ini juga disebabkan faktor budaya Minangkabau yang masih tabu terhadap KDRT. KDRT dalam budaya Minang bersifat pribadi dan sangat tertutup dan dapat diatasi sendiri dengan menganggap suaminya akan berubah serta berusaha mempertahankan rumah tangga (Hanani, 2012). Bagaimaanapun juga YI tetap mempertahankannya, terungkap dalam wancara dengan pernyataan bahwa:

"Saya kan pernah gagal pernikahan pertama. Prinsip saya, sudah kedua kali bagaimanapun meskipun tidak makanpun saya tetap pertahankan rumah tangga ini. Kalau berpisah selama 4 bulan pernah, tapi bersatu lagi. Misalnya, suami saya pendek umurnya, saya mau menikah lagi, tentunya orang lain itu pasti butuh keturunan dari saya dan bisa jadi belum tentu akan lebih baik dan saya hanya maut saja yang memisahkan meskipun banyak konflik". Sikap komitmen Yi diperkuat dari pernyataan "sudah cerai pernikahan pertama begitu buat saya down, namun saya berpikir ke depan pentingnya kasih sayang ayah kalau ayahnya masih ada dan saya tidak akan terpengaruh oleh perkataan orangtua saya (WW, 22 Mei 2020).

Jadi, dapat disimpulkan bahwa subjek kedua memiliki life satisfaction yang tinggi dalam integritas pribadi dibandingkan dengan subjek pertama. Subjek kedua lebih bersikap jujur, konsisten dan tetap berkomitmen untuk mempertahankaan rumah tangganya dengan pertimbangan tidak ingin gagal pada pernikahan yang kedua kalinya serta demi anak-anak. Kualitas kepuasasn hidup menurut YI lebih penting komitmen keluarga dibandingkan penderitaan KDRT yang dialaminya.

\section{Sense of family integrity (Integritas keluarga)}

Kondisi Sense of family integrity (integritas keluarga) yang baik dapat dilihat dalam menjalankan ibadah dan tepat dalam pengamalan nilai agama (Fautanu, 2011). Pada responden pertama dari hasil wawancara dan observasi pada, mengaku bahwa dalam menjalankan ibadah cukup baik. Ef menyatakan:"jujur saya selama ini sejak gadis jarang sholat, namun ketika kenal dan diajak dengan Teman sekaligus tetanggga yang baik, yang dikenal dengan nama Tek Nun, sampai saat ini saya tidak meninggalkan sholat wajib bahkan sholat ke mesjid". Ketika EF sedang mengalami krisis keuangan keluarga, salah satu solusi utama yang dia lakukan adalah menjalankan sholat (WW25042020).

Selanjutnya, hasil triangulasi wawancara dengan teman EF, EF punya masa lalu yaitu yang pernah terkena razia karena pernah bekerja sebagai tukang pijat dan pekerja salon. Teman EF juga sering menasehati, "apa gunanaya sholat jika masih melakukan perbuatan seperti itu" (WW25042020).

Pengamalan nilai agama seperti kesabaran dan sikap memaafkan EF cukup baik. Hal ini terbukti dalam pernyataan pada wawancara, menyatakan:

"kini mulai ada perubahan, terutama semakin lebih sabar dan siap" (WW10042020). Kesabaran EF juga diperkuat dengan pernyataan teman EF, "kalau sekarang sudah berkurang berbicara menentang terutama dengan suaminya. Itu saya nasehati harus sabar. karena sudah dewasa" (WW25042020). Selanjutnya sikap teang dan kesabaran EF juga nampak saat observasi yang dilakukan di rumah EF pada tanggal 18 Mei 2020, EF mampu menenangkan salah seorang tetangga sebellah yang marah kepada anaknya "Sabar ya Bu'de jangan marah, tu si Reka sedang di kamar sama Jihan". Sikap memaafkan EF juga cukup baik karena ketika EF selesai bertengkar, EF sering menjemput suaminya yang pergi ke rumah orangtuanya, "Ya, bisa menerima Pak, walaupun awalnya berat dan tidak memaafkan" (WW19032020). Kemudian 
keteladanan EF di keluarga cukup baik, contohnya EF dapat dijadikan model dalam menjalankan ajaran agama ketika di rumah.

Artinya, sikap sabar dan memaafkan dari subjek pertama (EF) cukup baik dalam upayanya sabar dan memeaafkan suaminya. Sebaliknya, responden kedua (YI) masih belum menjadi sosok teladan yang diharapkan, terungkap dalam wwancara dengan pernyataan:

\begin{abstract}
"Kalau saya jauh sekali ya tidak ada sholat. Ingin mengerjakannya tapi berat sekali. Entah karena Imam saya betul yang seperti itu jauh dari sholat. Kalau anak yang bungsu ada dia sholat baru belajar, Mama sholat kita lagi", kata anak" (WW09042020). Orangtua YI juga menjelaskan bahwa "Maaf bicara Nak, disuruh sholat tidak mau. Dia sering dirasuki syetan. Di atas rumah Ibu ni banyak syetan dan penghuni lainnya. Dia terkena gangguan terus" (WW30052020). Kondisi kurangnya keteladanan dalam menjalankan agama pada YI juga diperkuat dalam observasi yang dikakukan pada tanggal 16 Mei 2020 di rumah YI, YI dan suaminya tidak menjalankan ibadah puasa, "Uni dan Abang tidak berpuasa sama sekali, tapi si Farel yang Sd ini dia berpuasa".
\end{abstract}

Sisi lain, YI memiliki sikap memaafkan yang baik kepada suaminya yang sudah memeperlakukannya dengan kasar, "Kalau tidak ingin saya kembali ke rumah, berarti saya tidak memaafkannya" (WW09042020). Saya pernah pergi meninggalkan suaminya selama 4 bulan ke rumah orangtua YI. Beberapa kali YI menolak ditemui oleh suaminya, akhirnya YI mau dijemput pulang dan merasa memaafkan suamainya dengan ikhlas dan sabar.

Jadi, dapat disimpulkan bahwa life satisfaction pada aspek Sense of family integrity EF cukup baik dibandingkan YI dalam menjadi teladan menjalankan ajaran agama dan memiliki sikap sabar serta memaafkan suami. Sebaliknya, YI memiliki Sense of family integrity yang kurang baik terutama dalam menjadi teladan dan menjalankan agama. YI begitu sering melakukan kekasaran dan KDRT demi anakanaknya.

\title{
Kesimpulan
}

Hasil penelitian menunjukkan bahwa kondisi life satisfaction korban KDRT, sebagai berikut: subjek pertama memiliki sense of personality integrity (integritas pribadi) yang kurang bagus karena masih kurang jujur terhadap suami dan komitmen memepertahankan pernikahan masih labil karena memiliki hubungan khusus dengan pria lain. Sedangkan, subjek kedua memiliki sense of personality integrity yang bagus ketika mengalami KDRT karena tidak ingin gagal kedua kalinya dalam pernikahan dan berusaha mempertahankan keluarga demi kelangsungan anak-anaknya. $\mathrm{Hl}$ ini jug dipengaruhi oleh faktor budaya di Minangkabau yang begitu tertutup terhadap KDRT karena sesuatu yang tabu jika menuntut suami yang melakukan KDRT. Pada sense of family integrity, subjek pertama cukup baik dalam aspek menjalankan ibadah dan menjadi teladan yang baik dihadapan anak-anaknya. Sedangkan YI memiliki sense of family integrity yang kurang bagus dalam aspek menjalankan ibadah, belum menjdi sosok teladan yang baik dan masih kurang sabardalam mendidik. Namun, Responden pertama dan kedua sama-sama memeiliki sikap memaafkan yang baik terhdapa suaminya.Hasil penelitian menunjukkan, life satisfaction korban KDRT pada kedua subjek penelitian tergolong kurang baik secara integritas pribadi dan integritas keluarga. Namu, YI jauh lebih baik dalam kepuasan hidupnya meskipun mengalami KDRT. Kepuasan hipu YI lebih baik, terlihat pada integritas dalam komitmen menjaga keutuhan keluarga sangat besar. Implikasi dalam Bimbingan dan Konseling, diarahkan pada kajian kompetensi konselor dalam melakukan intervensi psikologis untuk mengembangkan life satisfaction korban KDRT.

\section{Referensi}

Abdurrachman, H. (2016). Perlindungan Hukum Terhadap Korban Kekerasan Dalam Rumah Tangga Dalam Putusan Pengadilan Negeri Sebagai Implementasi Hak-Hak Korban. Jurnal Hukum Ius Quia Iustum, 17(3), 475-491. https://doi.org/10.20885/iustum.vol17.iss3.art7

Afdal, A., Alizamar, A., Ifdil, I., Erlamsyah, E., \& Taufik, T. (2017). Guidance And Counseling Services For Women Victims Of Domestic Violence. Advances in Social Science, Education and Humanities Research, 118(23), 935-939. https://doi.org/10.2991/icset-17.2017.151

Afdal, A., Arnaldy, A., Nirwana, H., Alizamar, A., Zikra, Z., Ilyas, A., \& Fikri, M. (2019). Increasing life satisfaction of domestic violence victims through the role of supporting group therapy on social media. Advances in Social Science, Education and Humanities Research, Volume 372, 372(ICoET), 139-144.

Ainiyah, Q., \& Mufarida, L. (2019). Kufu Agama dalam Pernikahan, Peletak Dasar Pendidikan Islam dalam 
Keluarga Menuju Baiti Jannati, 3(1), 19-26. https://doi.org/10.21070/halaqa.v3i1.2120

Aressa, V., Nirwana, H., \& Bentri, A. (2016). Komunikasi interpersonal anak dan orangtua ditinjau dari jenis Kelamin , tingkat pendidikan orangtua, dan daerah tempat tinggal serta implikasinya pada bimbingan dan konseling. Konselor, 5(3), 1-12.

Arrasyid. (2019). Konsep kebahagiaan dalam tasawuf modern hamka. Jurnal Filsafat Dan Pemikiran Isalm, 19(1), 205-219.

Arya, M. (2017). Inilah Angka Kekerasan 4 Tahun Terakhir di Sumatera Barat. Retrieved from https://padangkita.com/inilah-angka-kekerasan-perempuan-4-tahun-terakhir-di-sumbar/

Asih, N. S., Yuliadi, I., \& Karyanta, N. A. (2010). Hubungan antara Konsep Diri dan Religiusitas dengan Kepuasan Hidup pada Lansia di Desa Rendeng Kabupaten Kudus. Jurnal Fakultas Kedokteran UNS, 1-12.

Avdibegovic, E., Brkic, M., \& Sinanovic, O. (2017). Emotional profile of women victims of domestic violence. Materia Socio Medica, 29(2), 109. https://doi.org/10.5455/msm.2017.29.109-113

Chang, L., McBride-Chang, C., Stewart, S. ., \& Au, E. (2003). Life Satisfaction, Self-Cconcept, and Family Relations in Chinese Adolescents and Children. International Journal of Behavioral Development, 27(2), 182189. https://doi.org/10.1080/01650250244000182

Corey, G. (2013). Theory and practice of counseling and psychotherapy. In E. M. Seth Dobrin, Naomi Dreyer, Suzanna Kincaid (Ed.), Theory and Practice of Counseling and Psychotherapy (Ninth Edit, pp. 136169). California: Brooks/Cole Cengage Learning. Retrieved from www.cengage.com/brookscole

Creswell, J. W. (2007). Research Design. (Diana E. Axelsen, Ed.) (Second Edi). London and New delhi: Sage Publication.

Dalimunthe, R. ., Marjohan, \& Syahniar. (2014). Kontribusi Pengasuhan Orangtua dan Self-Esteem terhadap Perilaku Bullying. Konselor, 3(4), 1-7.

Dinas Pemberdayaan Perempuan. (2017). Data Kekerasan Perempuan dan Anak. Padang.

Fautanu, I. (2011). Reaktualisasi ilai - nilai keislaman dan keindonesiaan untuk membangun karakter bangsa. Al-Risalah Jurnal Kajian Hukum Islam Dan Sosial Kemasyarakatan, 11(2), 1-13. https://doi.org/https://doi.org/10.30631/al-risalah.v11i02.465

Fergusson, McLeod, Horwood, Swain, Chapple, \& Poulton. (2015). Life satisfaction and mental health problems (18 to 35 years). Psychological Medicine, 45(11), 2427-2436. https://doi.org/10.1017/S0033291715000422

Field, S., Onah, M., Heyningen, T. V, \& Honikman, S. (2018). Domestic and intimate partner violence among pregnant women in a low resource setting in South Africa: A facility-based, mixed methods study. $B M C$ Women's Health, 18(1), 1-13. https://doi.org/10.1186/s12905-018-0612-2

Gustin, W. I., \& Jatiningsih, O. (2017). Upaya istri sebagai korban kekerasan dalam menyikapi kdrt di kabupaten mojokerto. Kajian Moral Dan Kewarganegaraan, 5(3), 767-783.

Hanani, S. (2012). Mengatasi kekersan dalam rumah tangga melalui institusi adat minangkabau ( suatu upaya dalam mewujudkan kesejahteraan berbasis perspektif lokalitas dan religius ). Conference Proceeding AICIS, XII, 573-591. Retrieved from igilib.uinsby.ac.id

Hurlock, E. B. (2004). Psikologi perkembangan, suatu pendekatan sepanjang rentang waktu kehidupan. Jakarta: Erlangga.

Kabasakal, Z. (2015). Life satisfaction and family functions as-predictors of problematic Internet use in university students. Computers in Human Behavior, 53, 294-304. https://doi.org/10.1016/j.chb.2015.07.019

Kantor Urusan Agama Kecamatan Padang Barat. (2019). Data Konflik Rumah Tangga Rentang Tahun 2017 s.d Februari 2019. Padang.

Kaur, R., \& Garg, S. (2016). Domestic violence against women: a qualitative study in a rural community. Asia Pac Jurnal Public Health, 20(10), 1-10. https://doi.org/10.1177/1010539509343949

Kesowo, B. (2004). Undang-Undang Republik Indonesia Nomor 23 Tahun 2004 tentang Penghapusan Kekerasan Dalam rumah Tangga. Jakarta, Indonesia. Retrieved from www.bphn.go.id

Khumairoh, B., \& Undarwati, A. (2015). Hubungan antara adult attachment style dengan komitmen pernikahan pada dewasa awal. Jurnal Intuisi Ilmiah Psikologi, 7(1), 28-34.

Komnas Perempuan. (2019). Catatan Kekerasan Terhadap Perempuan Tahun 2018. Jakarta.

Lim, C., \& Putnam, R. . (2010). Religion, social networks, and life satisfaction. American Sociological Review, 75(6), 914-933. https://doi.org/10.1177/0003122410386686

Linsiya, R. . (2015). Perbedaan ingkat kepuasan hidup antara mahasiswa Strata 1 (S1) dan Strata 2 (S2). Psycology Forum UMM, 1(7), 284-287. Retrieved from http://mpsi.umm.ac.id/files/file/284-287 Ria Wiyatfi.pdf

Maddux, J. E. (2018). SUBJECTIVE WELL- BEING AND LIFE SATISFACTION (First). New York: Routledge Taylor \& Francis. 
Miles, M. ., \& Huberman, A. . (1992). Qualitative data analysis: A sourcebook of new methods. (Second Edi). California: Sage.

Muhid, A., Nurmamita, P. E., \& Hanim, L. M. (2019). Resolusi Konflik dan Kepuasan Pernikahan : Analisis Perbandingan Berdasarkan Aspek Demografi. MEDIAPSI, 5(1), 49-61.

Najarpourian, S., Fatehizadeh, M., Etemadi, O., Ghasemi, V., Abedi, M. R., \& Bahrami, F. (2012). Personality Types and Marital Satisfaction. Interdisciplinary Journal of Contemporary Research in Business, 4(5), 372-383. Retrieved from ijcrb.webs.com

Nirwana, H. (2012). Pengungkapan Diri Siswa Sekolah Menengah Dan Implikasinya Bagi Konseling. Ilmu Pendidikan, 18(1), 1-7.

Nockita, C. . (2016). Self Compassion dan Kepuasan Hidup Istri Korban KDRT. Universitas Muhammadiyah Malang.

Nurhayati, S. ., Suardiman, S. ., \& Sanyata, S. (2010). Dukungan sosial dan strategi menghadapi masalah perempuan korban kdrt. Jurnal Penelitian Humaniora, 15(1), 23-38.

Rahardjo, W. (2007). Penganiayaan Emosional Dan Kekerasan Dalam Rumah Tangga : Jurnal Penelitian Psikologi, 12(1), 1-11.

Ramadani, M., \& Yuliani, F. (2017). Kekerasan Dalam Rumah Tangga (Kdrt) Sebagai Salah Satu Isu Kesehatan Masyarakat Secara Global. Jurnal Kesehatan Masyarakat Andalas, 9(2), 80. https://doi.org/10.24893/jkma.9.2.80-87.2015

Rambe, S. A., Mudjiran, M., \& Marjohan, M. (2018). Pengembangan Modul Layanan Informasi untuk Mengembangkan Kontrol Diri dalam Penggunaan Smartphone. Konselor, 6(4), 132. https://doi.org/10.24036/02017648051-0-00

Soeroso, H. . (2012). Kekerasan Dalam Rumah Tangga Dalam Perspektif Yuridis-Viktimologis. (Tarmizi, Ed.) (1.Cet.3). Jakarta: Sinar Grafika.

State, T. M., \& Kern, L. (2017). Life Satisfaction Among High School Students With Social, Emotional, and Behavioral Problems. Journal of Positive Behavior Interventions, 19(4), 205-215. https://doi.org/10.1177/1098300717714573

Stith, S. ., Green, N. ., Smith, D. ., \& Ward, D. . (2008). Marital satisfaction as a risk marker for intimate partner physical violence: A meta-analytic review. Journal of Family Violence, 23, 149-160. https://doi.org/10.1007/s10896-007-9137-4

Sumiarti, A., \& Puspitawati, H. (2017). The Relationship between Domestic Violence, Social Support, and Self Esteem Women Victims. Journal of Family Sciences, 2(2), 34. https://doi.org/10.29244/jfs.2.2.34-44

Syatibi, D. A. (2013). Nasihat bagi para pencari cahaya. (N. S. Djalaluddin \& S. L. D, Eds.) (1st ed.). Bandung: Syamil books.

Tamelab, P. (2020). Menyoroti Fenomena KDRT Pada Keluarga-Keluarga di Paroki Spiritu Santo Misir dalam Terang Efesus. Pastoralia, 5, 22-33. Retrieved from pastoralia.net

Tsirigotis, K., \& Łuczak, J. (2016). Emotional Intelligence of Women Who Experience. Psychiatric Quarterly, 87(1), 165-176. https://doi.org/10.1007/s11126-015-9368-0

Vassar, M. (2012). Psychology of Life Satisfaction. (Matt Vassar, Ed.). New York: Nova Science Publisher, Inc.

WHO. (2017). Violence Against Women: Intimate Partner and Sexual Violence Against Women. Retrieved from www.who.int/reproductivehealth

Wulandari, S. (2016). Penyesuaian Diri Siswa Kelas X Smk Santa Maria Jakarta. Jurnal Psiko-Edukasi, 14(2), 94-100.

Yeni, A., \& Lianawati, E. (2009). Gambaran model agresivitas umum pada pelaku kekerasan dalam rumah tangga penganiayaan. Jurnal Psikologi, (2009), 1-12. 